\title{
An exploratory study on the feasibility and challenges of implementation of Right to Education Act (RTE)
}

\author{
Dr. Neeta Sinha*, Mr. Yashvardhan Verma**
}

Keywords: Education Act (RTE)

\section{INTRODUCTION}

The enforcement of the Right to Education Act brings the country closer to achieving the objectives and mission of the Millennium Development Goals (MDGs) and Education for All (EFA) and hence is a historic step taken by the Government of India.

Article 21-A and the RTE Act came into effect on 1 April 2010. The title of the RTE Act incorporates the words 'free and compulsory'. 'Free education' means that no child, other than a child who has been admitted by his or her parents to a school which is not supported by the appropriate Government, shall be liable to pay any kind of fee or charges or expenses which may prevent him or her from pursuing and completing elementary education. 'Compulsory education' casts an obligation on the appropriate Government and local authorities to provide and ensure admission, attendance and completion of elementary education by all children in the 6-14 age group. With this, India has moved forward to a rights based framework that casts a legal obligation on the Central and State Governments to implement this fundamental child right as enshrined in the Article 21A of the Constitution, in accordance with the provisions of the RTE Act.

According to Richard Wasserstorm it means, one ought to be able to claims as entitlements (i.e. human rights) those minimal things without which it is impossible to develop ones capabilities and to live life as human beings. Thus Human Rights is about balancing the rights of all of us as individual within the community.

The right to education is a universal entitlement to education, recognized in the International Covenant on Economic, Social and Cultural Rights as a human right that includes the right to free, compulsory primary education for all.

*Asst. Professor, Dept of Psychology, School of Liberal Studies, Pandit Deendayal Petroleum University, Raisan, Gandhinagar, India.

**Student (Delhi University) New Delhi

(C) 2014 N Sinha, Y Verma; licensee IJIP. This is an Open Access Research distributed under the terms of the Creative Commons Attribution License (http://creativecommons.org/licenses/by/2.0), which permits unrestricted use, distribution, and reproduction in any Medium, provided the original work is properly cited. 
The right to education is a law in Article 26 of the Universal Declaration of Human Rights and Articles 13 and 14 of the International Covenant on Economic, Social and Cultural Rights.

The right to education has been reaffirmed in the 1960 UNESCO Convention against Discrimination in Education, the 1981 Convention on the Elimination of All Forms of Discrimination Against Women, ${ }^{[4]}$ and the 2006 Convention on the Rights of Persons with Disabilities $^{[5]}$

In Europe, Article 2 of the first Protocol of 20 March 1952 to the European Convention on Human Rights states that the right to education is recognized as a human right and is understood to establish an entitlement to education. According to the International Covenant on Economic, Social and Cultural Rights, the right to education includes the right to free, compulsory primary education for all, an obligation to develop secondary education accessible to all in particular by the progressive introduction of free secondary education, as well as an obligation to develop equitable access to higher education in particular by the progressive introduction of free higher education. The right to education also includes a responsibility to provide basic education for individuals who have not completed primary education. In addition to this access to education provisions, the right to education encompasses also the obligation to eliminate discrimination at all levels of the educational system, to set minimum standards and to improve quality

The Constitution (Eighty-sixth Amendment) Act, 2002 inserted Article 21-A in the Constitution of India to provide free and compulsory education of all children in the age group of six to fourteen years as a Fundamental Right in such a manner as the State may, by law, determine. The Right of Children to Free and Compulsory Education (RTE) Act, 2009, which represents the consequential legislation envisaged under Article 21-A, means that every child has a right to full time elementary education of satisfactory and equitable quality in a formal school which satisfies certain essential norms and standards.

\section{The RTE in India Act provides for the:}

(i) Right of children to free and compulsory education till completion of elementary education in a neighborhood school.

(ii) It clarifies that 'compulsory education' means obligation of the appropriate government to provide free elementary education and ensure compulsory admission, attendance and completion of elementary education to every child in the six to fourteen age group. 'Free' means that no child shall be liable to pay any kind of fee or charges or expenses which may prevent him or her from pursuing and completing elementary education.

(iii) It makes provisions for a non-admitted child to be admitted to an age appropriate class. 
(iv) It specifies the duties and responsibilities of appropriate Governments, local authority and parents in providing free and compulsory education, and sharing of financial and other responsibilities between the Central and State Governments.

(v) It lays down the norms and standards relating inter alia to Pupil Teacher Ratios (PTRs), buildings and infrastructure, school-working days, teacher-working hours.

(vi) It provides for rational deployment of teachers by ensuring that the specified pupil teacher ratio is maintained for each school, rather than just as an average for the State or District or Block, thus ensuring that there is no urban-rural imbalance in teacher postings. It also provides for prohibition of deployment of teachers for non-educational work, other than decennial census, elections to local authority, state legislatures and parliament, and disaster relief.

(vii) It provides for appointment of appropriately trained teachers, i.e. teachers with the requisite entry and academic qualifications.

(viii) It prohibits (a) physical punishment and mental harassment; (b) screening procedures for admission of children; (c) capitation fee; (d) private tuition by teachers and (e) running of schools without recognition,

(ix) It provides for development of curriculum in consonance with the values enshrined in the Constitution, and which would ensure the all-round development of the child, building on the child's knowledge, potentiality and talent and making the child free of fear, trauma and anxiety through a system of child friendly and child centered learning.

Besides this there are several other detailed features of the act which are not mentioned here due to space constraint.

The Act maintains that All children upto 14yrs if age have the right to free and compulsory education. The child cannot be denied the right to admission to a school of their choice on the basis of class, caste or income. This study is focused on the challenges and concerns of the implementation of Right to Education Act into the society. The study hereby focuses on the lacunae in the provisions of the RTE Act and the challenges of implementation

\section{SOCIAL CHALLENGES:}

\section{Neighborhoods criteria}

The neighborhoods criterion mentions that the school should be within $4 \mathrm{kms}$ of the residence of the child. But what if no good school is available within the $4 \mathrm{kms}$ area? In such a situation the parents may be forced to put the child in a not so good school and the child may be deprived of 
quality education. Chances are that these being slum areas good school may not be available in the neighborhood. The neighborhood restrictions may limit the disadvantaged residents to access only these schools.

Besides there are chances that there are no schools within the $4 \mathrm{kms}$ area at all. What happens in such cases? In India there are many small towns and villages where no schools are available, so what does the parent of the young child do in this case. The parents in this case have only two choices (i) To make the child sit at home and let him/her remain illiterate (ii) To send the child to a far off school which would be both time and money consuming. (iii) Spend exorbitant amount on daily commute (iv) Compromising with the health and safety concerns of the children.

In many of the rural as well as urban areas the public transport system is not so good. In this case it is almost impossible for the children to reach school considering the fact that since they come from underprivileged background they cannot afford to bear the cost of hiring an auto of taxi, nor do the parents have vehicles of their own for pick up and drop.

Travelling to long distance on a daily basis may take a toll on the health of the young children. In the extreme Indian weather conditions it would not be feasible for the children to commute daily. The heat, the dust and the fumes may take its toll on the health of the young children and they may develop complications.

\section{Insufficient Per child expenditure}

The government proposes to reimburse the expense incurred to the private school, but in most of the cases the private schools are far too expensive. The fees that the private schools charge is way beyond the pockets of even middle class people, but since education is the key to child's growth, the parents do not really mind paying higher fees even though it may not be economically viable.

The amount the government proposes to reimburse is the same as the cost it incurs in the government schools per child which is very nominal. The government aided and government schools charge a very nominal amount from the parents. In such a situation the private schools many a times end up charging additional fees from the children of the upper strata thus making those parents bear additional expenses. Considering the fact that the parents are already paying quite a heavy sum, it puts additional and unreasonable pressure on the parent's pockets.

There is no mention whether the entire amount incurred by the school towards the education of the underprivileged would be transferred monthly, quarterly, half-yearly or yearly, thus making the planning process inconvenient. If the schools would be told in advance about the schedule of reimbursement it would help in better planning and implementation. It would help the school plan the budget deficit and activities accordingly.

The act does not mention at what frequency the expenses would be recalculated. Should it calculate every two years or does it go according to the consumer price index. Because in these 
times of constant inflation the deficits go on increasing, so how does the school take care of this? With the prices increasing frequently it becomes imperative that some time frame be given for the revision of the expenses.

\section{Lack of awareness}

According to the present regulation $25 \%$ seats to be reserved for children from underpriviledged section. In many cases these seats are not be filled due to unawareness on parts of the parents. In such a situation it leads to loss to the school because they are not even empowered to fill these seats with children of the upper strata. Hence provision should be made by the Government to spread proper awareness about the RTE Act and its provisions. Campaigns should be held, street plays, mohalla meetings, short movies/ documentaries to be shown. Posters to be put up. NGOs should also undertake the task of not only creating awareness but also helping the under privileged secure admissions' to these schools. Mostly these parents are unaware and illiterate themselves and have no means to secure admission to the private schools.

The present study is based on the interactions that the author had with various private school authorities. (for the purpose of confidentiality the names of the school and resource persons are withheld)

\section{Who is Eligible?}

The Act does not stipulate the eligibility criteria for the selection of the candidate, i.e. it does not talk about the income levels of the parents and thereafter the eligibility of the child. Weaker section is a very vast term. Till what income levels are we talking about? How would that be determined? Anybody can use unfair means to get the benefits of the act even though they may not be eligible. Detailed guidelines need to be given with respect to the eligibility criteria. Also careful monitoring is needed to ensure the benefits to the needy and the deprived.

\section{Conclusion}

Therefore looking at all these and many more of such issues the government needs to ensure that for the smooth functioning of the act and for the benefit to reach the much needed sections of the society, some more detailing and alterations in the act is required. The weaker section of the society who actually needs to get the benefit is hardly informed about the act and its provisions. Therefore a lot of effort needs to be made both on part of the government, NGOs and alert citizens to make the underprivileged people aware of their rights, the facilities and the services being provided. If we are looking towards an educated India we really need to put in a lot of effort to ensure that the benefits reach the needy and the target of being a literate country is achieved 


\section{REFERENCES}

1. Advantages and disadvantages of RTE Act, The Hindu, May 23, 2013http://www.thehindu.com/news/cities/Madurai/advantages-and-disadvantages-of-rteact/article4735501.ece. Accessed on $4^{\text {th }}$ July

2. Burt H.E.,(1946) Applied Psychology, Prentice Hall, New York.

3. http://www.unicef.org/india/education_6144.htm

4. India Govt Archive http://www.archive.india.gov.in/citizen/education.php?id=38

5. Ministry of HRD, Department of School Education and Literacy, Sarva Shiksha Abhiyan (2009) Retrieved from http://ssa.nic.in/quality-of-education/right-of-children-to-free-andcompulsory-education-act-2009, 4-7-2014

6. Niranjanaradhya V P and Abhinav Jha (2013), Right of Children to Free and Compulsory Education ACT - Miles to Go...A Case Study of a Gram Panchayat, Books for change: Bangalore https://www.nls.ac.in/ccl/cclmedia/ER/miles.pdf

7. S. Venkatesh, "The social organization of street gang activity in an urban ghetto", American Journal of Sociology, vol. 103, No. 1 (July 1997), pp. 82-111.

8. Sharma Ramnath and Sharma Rachna (2004) Advanced Applied Psycchology Vol.II, Atlantic Publishers and Distributors, New Delhi.

9. Shekhar Mittal and Parth J Shah, Reservation in Private Schools under the Right to Education Act: Model for Implementation. Centre for Civil Society.

10. World Youth Report 2003 Chapter 7 Juvenile Delinquency http://www.un.org/esa/socdev/unyin/documents/ch07.pdf Retreived on 14-7-2014 